$\begin{array}{ll}\text { Received } & : 25 \text { May } 2019 \\ \text { Revised } & : 29 \text { May } 2019 \\ \text { Accepted } & : \text { 22 June } 2019 \\ \text { Published } & : \text { 30 June } 2019\end{array}$

\title{
Language Error Analysis in MPBI-UMS Students Speech Who Roled as Police Officers
}

\author{
Anam Purwanto $^{1, \mathrm{a})}$, Markhamah ${ }^{1, \mathrm{~b})}$ \\ ${ }^{1}$ Program Studi Magister Pendidikan Bahasa Indonesia \\ Program Sekolah Pascasarjana, Universitas Muhammadiyah Surakarta \\ Jalan A. Yani Tromol Pos 1 Pabelan Kartasura Telp. (0271) 717417-719483 \\ Fax. (0271) 715448 Surakarta 57102, Jawa Tengah, Indonesia \\ E-mail: a) anampurwanto16@gmail.com, ${ }^{\text {b) }}$ markhamahums@yahoo.com
}

\begin{abstract}
This study aims to describe language errors made by the Klaten police officers when giving speeches. The method used in this study is qualitative. The data collection technique used is refer to and record. The data analysis method used is the Agih method. Data analysis techniques use extending techniques and reading merkah techniques. The results of this study were (1) phonological errors 5. (2) spelling field errors 1. (3) morphological errors, 1 pleonasms, and 9 prepositions. (4) syntax errors, 6 word waste errors, 6 repetition errors and 1 sentence ineffectiveness. (5) sociolinguistic errors, 3 code switching errors.
\end{abstract}

Keywords: errors, language, syntax, sociolinguistics

\begin{abstract}
Abstrak
Penelitian ini bertujuan untuk mendeskripsikan kesalahan berbahasa yang dilakukan oleh polisi Klaten pada saat berpidato. Metode yang digunakan dalam penelitian ini adalah kualitatif. Teknik pengumpulan data yang digunakan adalah simak dan catat. Metode analisis data yang digunakan adalah metode agih. Teknik analisis data menggunakan teknik padan referensial, padan fonetis artikulatoris, dan teknik baca markah. Hasil penelitian ini meliputi (1) kesalahan bidang fonologi ditemukan lima kesalahan, (2) kesalahan bidang ejaan ditemukan satu kesalahan, (3) kesalahan bidang morfologi ditemukan satu pleonasme dan sembilan kesalahan penggunaan kata depan, (4) kesalahan bidang sintaksis ditemukan enam kesalahan kemubaziran kata, enam kesalahan repetisi, dan satu ketidakefektifan kalimat, (5) kesalahan bidang sosiolinguistik ditemukan tiga kesalahan alih kode.
\end{abstract}

Kata kunci: kesalahan, berbahasa, sintaksis, sosiolinguistik 


\section{PENDAHULUAN}

Bertutur merupakan salah satu kegiatan berbahasa yang biasa dilakukan oleh manusia. Kegiatan tersebut membutuhkan adanya bahasa yang telah disepakati bersama. Menurut Chaer (2007), sebagai alat komunikasi manusia, bahasa adalah suatu sistem yang bersifat sistematis dan sistemis. Sistematis adalah bahasa itu bukan suatu sistem tunggal, melainkan terdiri pula dari beberapa subsistem, yaitu subsistem fonologi, subsistem morfologi, dan subsistem semantik. Bahasa merupakan alat komunikasi yang berupa sistem lambang yang dihasilkan oleh alat ucap manusia (Noviastuti, Arifah, \& Murtiani, 2017). Berbicara, salah satunya adalah berpidato, merupakan kemampuan mengucapkan bunyi-bunyi artikulasi atau kata-kata untuk mengekspresikan, menyatakan, atau menyampaikan pikiran, gagasan, dan perasaan (Marsono, 2015). Dengan demikian, dapat disimpulkan bahwa berbicara merupakan pengungkapan suatu sistem tanda-tanda atau lambang-lambang bahasa secara lisan.

Wiyanti (2014) menjelaskan bahwa keterampilan berbicara dianggap sebagai salah satu kemampuan berbahasa yang menjadi tolok ukur dalam menentukan kualitas kemampuan berpikir seseorang. Berbicara merupakan ekspresi dari gagasan gagasan seseorang yang menekankan komunikasi yang bersifat dua arah, yaitu memberi dan menerima. Kemampuan berpikir seseorang dalam mengekspresikan gagasan-gagasan akan tampak saat ia berbicara.

Setiap tuturan tidak selalu terujar dengan sempurna. Sangat mungkin terjadi kesalahan ketika seorang individu berbicara. Dalam kaitannya dengan kesalahan berbahasa, dikenal dua istilah, yaitu (1) kesalahan berbahasa atau error, dan (2) kekeliruan berbahasa atau mistake (Markhamah dan Sabardila, 2014). Kesalahan berbahasa adalah penyimpangan yang bersifat sistematis, konsisten, dan menggambarkan kemampuan peserta didik pada tahap tertentu (yang biasanya belum sempurna). Sementara itu, kekeliruan adalah bentuk penyimpangan yang tidak sistematis yang berada pada wilayah performansi atau perilaku berbahasa. Kekeliruan atau mistake cenderung diabaikan dalam analisis kesalahan berbahasa. Hal tersebut disebabkan oleh sifatnya yang tidak acak, individual, tidak sistematis,dan tidak permanen (Nurwicaksono \& Amelia, 2018). Akan tetapi, kesalahan berbahasa yang dibuat oleh siswa harus dikurangi sampai ke batas sekecil-kecilnya.

Fenomena kesalahan berbahasa dapat terjadi pada situasi atau bidang-bidang tertentu terutama pada pemakaian bahasa yang tidak hanya mengutamakan faktor komunikatif sebagai hasil akhir dalam aktivitas berbahasa, tetapi juga memperhatikan kaidah berbahasanya (Johan \& Yusrawati, 2017; Suhartatik, 2018; Purwahida, 2018). Dalam hal ini penulis menganalisis keterampilan berbicara seorang polisi di Klaten ketika menyampaikan pidato.

Terkait dengan keterampilan berbicara, penelitian keterampilan berbahasa sudah banyak dilakukan, antara lain sebagai berikut. Afifah \& Widodo (2015) meneliti Kesalahan Deiksis dalam Karangan Mahasiswa pada Niveau A2 di Jurusan sastra Jerman UM. Marsono (2015) meneliti Meningkatkan Keterampilan Pidato melalui Perpaduan Metode Simulasi Lomba Pidato Bahasa Indonesia dengan Model Talking Stick pada Siswa Kelas XII IPA 2 SMA Negeri Meulaboh Kabupaten Aceh Barat. Afifah dan Hasibuan (2018) meneliti Kesalahan Berbahasa pada Penulisan Media Luar Ruang di Wilayah Kota Medan. Mokhtar (2000) meneliti Interferensi Morfologis Penutur Bahasa Bugis dalam Berbahasa Indonesia. Hasyim (2008) meneliti Faktor Penentu Penggunaan bahasa pada Masyarakat Tutur Makassar: Kajian Sosiolinguistik 
di Kabupaten Gowa. Johan dan Ghasya (2017) meneliti Analisis Kesalahan Morfologis dalam Proses Diskusi Siswa Sekolah Dasar.

\section{METODE PENELITIAN}

Jenis penelitian ini adalah penelitian kualitatif. Sugiyono (dalam Rohmadi \& Nasucha, 2015) menjelaskan bahwa metode kualitatif adalah metode penelitian yang berlandaskan pada filsafat postpositivisme. Afrizal (2016) menyatakan bahwa metode penelitian kualitatif adalah metode penelitian ilmu-ilmu sosial yang mengumpulkan dan menganalisis data berupa kata-kata, baik lisan maupun tulisan, dan peneliti tidak berusaha menghitung data kualitatif yang telah diperoleh atau tidak menganalisis angkaangka.

Sudaryanto (2015) menyatakan bahwa untuk menggali permasalahan yang akan dikaji dibutuhkan sebuah teknik analisis data. Teknik analisis data yang digunakan berupa teknik-teknik dalam metode padan. Metode padan yang digunakan padan fonetis artikulatoris dan padan referensial. Selain itu, metode agih digunakan untuk menemukan kalimat yang mengandung kesalahan berbahasa. Metode padan yang digunakan dalam penelitian ini berupa teknik dasar yaitu teknik Pilah Unsur Penentu (PUP). Hal yang dipakai analisis dalam teknik PUP ini ialah padan referensial. Adapun teknik yang digunakan dalam metode agih berupa teknik perluasan. Teknik ini dilakukan dengan memperluas satuan lingual. Selan itu, digunakan tekni analisis yang lain berupa teknik baca markah. Teknik baca markah diterapkan dengan melihat langsung pemarkah yang terdapat dalam data. Adapun dengan melihatnya, hal itu dilakukan baik secara sintaksis maupun secara morfologis (Sudaryanto, 2015). Uji keabsahan data dalam penelitian ini menggunakan triangulasi teori.

\section{HASIL DAN PEMBAHASAN}

Analisis kesalahan berbahasa memiliki hubungan erat dengan linguistik (Rahmawati, 2014). Bentuk kesalahan berbahasa yang ditelaah dalam penelitian ini meliputi lima bidang, yaitu (a) bidang fonologi, (b) kesalahan bidang ejaan, (c) morfologi, (d) sintaksis, dan (e) sosiolinguistik.

\section{Kesalahan Bidang Fonologi}

Kesalahan berbahasa bidang fonologi terdiri dari kesalahan perubahan fonem pembentukan fonem, dan kesalahan pelafalan (Setyawati, 2010; Markhamah \& Sabardila, 2014; Kim, 2015; Thoyib \& Hamidah, 2018). Adapun contoh mengenai kesalahan bidang fonologi disajikan sebagai berikut.

(1) Alhamdulillahirobil alamin, Segala puji hanya untuk Alloh Subhanahu Wataala (M/S200180010)

(2) Hindari berita hoak yang disebarluaskan melalui media sosial. Bagi para ibu-ibu dimohon untuk tidak secara cepat menyebarkan segala berita yang diterima melalui aplikasi. (M/S200180010)

(3) Hal ini perlu diterapkan di dalam prose demokrasi, khususnya dalam pemilu 2019 (M/S200180010)

(4) Dalam proses penerimaan dan pemberiaan informasi. (M/S200180010)

(5) Kemudian untuk jajaran saya, untuk para polisi di Kabupaten Klaten silahkan jaga 
netralitas dalam pemilu dengan tujuan menjaga proses pemilu agar berjalan damai, tidak melakukan tindakan-tindakan yang tidak humanis (M/S200180010)

Kesalahan berbahasa pada data (1), (2), dan (3) merupakan kesalahan berbahasa penghilangan fonem. Penulisan kata data (1) Alhamdulillahirobil terjadi penghilangan fonem konsonan /b/. Penulisan kata data (2) hoak, dan prose terjadi penghilangan fonem konsonan /s/. Kata data (3) hoak seharusnya diganti dengan penulisan hoaks yang berarti adalah berita bohong dan kata prose diganti dengan kata proses. Kesalahan berbahasa pada contoh (4) dan (5) adalah penulisan yang kurang tepat. Seharusnya, pada data (4), kata pemberiaan ditulis dengan pemberian dan kata silahkan pada data (5) ditulis dengan kata silakan. Adapun pembenaran data (1) sampai (5) adalah sebagai berikut.

(1a) Alhamdulillahirobbil alamin, Segala puji hanya untuk Alloh Subhanahu Wataala. (M/S200180010)

(2a) Hindari berita hoaks yang disebarluaskan melalui media sosial. Bagi para ibu-ibu dimohon untuk tidak secara cepat menyebarkan segala berita yang diterima melalui aplikasi. (M/S200180010)

(3a) Hal ini perlu diterapkan di dalam proses demokrasi, khususnya dalam pemilu 2019 (M/S200180010)

(4a) Dalam proses penerimaan dan pemberian informasi. (M/S200180010)

(5a) Kemudian untuk jajaran saya, untuk para polisi di Kabupaten Klaten silakan jaga netralitas dalam pemilu dengan tujuan menjaga proses pemilu agar berjalan damai, tidak melakukan tindakan-tindakan yang tidak humanis (M/S200180010)

Hasil penelitian ini relevan dengan penelitian Santosa dan Sabardila (2018) yang meneliti Analisis Kesalahan Berbahasa Pidato Mahasiswa MPB-UMS yang Memerankan Diri menjadi Calon Kepala Daerah Kabupaten Blora. Penelitian tersebut menemukan kesalahan fonologi yang erat kaitannya dengan penghilangan fonem atau penambahan fonem, baik fonem vokal maupun konsonan.

\section{Kesalahan Bidang Ejaan}

Kesalahan penggunaan tanda baca merupakan kesalahan yang berhubungan dengan kurang tepatnya atau belum adanya tanda baca dalam suatu kalimat. Dalam penelitian ini ditemukan kesalahan dalam penggunaan tanda baca.

(6) Dalam artian, kita mengenal semboyan bhineka tunggal ika. (M/S200180010)

Seperti yang telah dipaparkan, kesalahan berbahasa bidang ejaan berkaitan dengan pelafalan dan ortografis. Pada data (6), ditemukan kesalahan dalam penulisan huruf kapital. Penulisan kata bhineka tunggal ika seharusnya Bhineka Tunggal Ika karena merujuk pada semboyan dari sebuah negara. Adapun pembenaran data (6) adalah sebagai berikut

(6a) Dalam artian, kita mengenal semboyan Bhineka Tunggal Ika (M/S200180010)

Hasil penelitian ini juga relevan dengan penelitian Santosa dan Sabardila (2018) yang meneliti Analisis Kesalahan Berbahasa Pidato Mahasiswa MPB-UMS yang Memerankan Diri menjadi Calon Kepala Daerah Kabupaten Blora yang juga menemukan kesalahan bidang ejaan. 


\section{Kesalahan Bidang Morfologi}

Kesalahan bidang morfologi berhubungan dengan tata bentuk kata, derivasi, diksi, kontaminasi, dan pleonasme (Pateda, 1990). Adapun temuan contoh mengenai kesalahan bidang morfologi disajikan sebagai berikut.

(7) Yang mana Allah telah melimpahkan begitu rahmat dan hidayahnya yang sangat banyak sekali (M/S200180010)

(8) Yang kedua, Masyarakat jangan terprovokasi terhadap isu-isu yang bertujuan untuk memecah belah persatuan antar masyarakat (M/S200180010)

(9) Karena pada pemilu 2019 ini sangat rentan terhadap isu-isu yang bermuatan tentang Agama. (M/S200180010)

(10) Jika dulu seseorang bertemu dengan kiai, yang dipikirkan adalah Kiai tersebut spesialisasi ilmu bidang apa. (M/S200180010)

(11) Tetapi pada saat ini jika ada seseorang yang bertemu Kiai, Pertanyaannya adalah Kiai itu mendukung siapa. (M/S200180010)

(12) Tentu, agama menjadi landasan bernegara, berbangsa, dan berpolitik. (M/S200180010)

(13) Tetapi, agama tidak boleh dipolitisasi, itu mampu menghancurkan kesatuan dan keamanan bangsa Indonesia, Khususnya di Kabupaten Klaten (M/S200180010)

(14) Apalagi, anak-anak muda, jangan menggunakan kendaraan untuk meresahkan warga masyarakat (M/S200180010)

(15) Yang menganggu pendengaran para pengguna jalan yang lainnya (M/S200180010)

(16) Dan yang terakhir kepada ormas, silahkan menyebarluaskan pesan-pesan damai terkait pelaksanaan pemilu (M/S200180010)

Kesalahan pada data (7) termasuk dalam kesalahan pleonasme. Kesalahan pleonasme adalah kesalahan yang disebabkan oleh ketidaksengajaan penulis atau pembicara dalam menyampaikan kalimat. Jadi, pada hakikatnya pengertian pleonasme adalah pemakaian kata yang mubazir atau berlebihan dan sebenarnya tidak perlu, baik sebagai penegas arti maupun sebagai gaya. Dengan kata lain, jika kata yang dianggap sebagai pleonasme dihilangkan salah satu, makna kalimat akan tetap utuh (Markhamah, 2013). Selain penulisan frasa pada data (7) sangat banyak sekali, pada data (7) juga terdapat penggunaan kata depan yang tidak tepat, yaitu pada kata yang. Penggunaan kata depan tidak boleh menggunakan kata penghubung atau konjungsi. Data (8), (9), (10), (11), (12), (13), (14), (15), (16) termasuk kesalahan berbahasa dalam penggunaan kata depan. Penggunaan kata depan dalam kalimat tidak boleh menggunakan konjungsi atau kata penghubung. Konjungsi seharusnya tidak digunakan di awal kalimat, melainkan di tengah kalimat yang berfungsi sebagai penghubung antarkalimat.

Pada data (8) dan (15) terdapat kesalahan penggunaan konjungsi yang. Hal itu menjadikan kedua kalimat tersebut tidak efektif. Pada penulisan data (9) terdapat kesalahan penggunaan kata depan yang diawali dengan konjungsi karena. Seharusnya kalimat pada data (9) cukup ditulis Pemilu 2019 ini sangat rentan terhadap isu-isu yang bermuatan tentang agama. Penulisan data (10) terdapat kesalahan penggunaan konjungsi jika. Penulisan data (11) dan (13) terdapat kesalahan penggunaan konjungsi tetapi. Pada data (14) terdapat kesalahan penggunaan konjungsi yaitu kata apalagi. Seharusnya cukup ditulis dengan Anak-anak muda, jangan menggunakan kendaraan untuk meresahkan warga. Pada penulisan data (16) terdapat kesalahan penggunaan 
konjungsi dan. Data (16) dapat ditulis Imbauan yang terakhir kepada ormas, silakan menyebarluaskan pesan-pesan damai terkait pelaksanaan pemilu. Adapun pembenaran data (7) sampai (16) sebagai berikut.

(7a) Allah telah melimpahkan begitu banyak rahmat dan hidayah-Nya (M/S200180010)

(8a) Kedua, masyarakat jangan terprovokasi terhadap isu-isu yang bertujuan untuk memecah belah persatuan antarmasyarakat (M/S200180010)

(9a) Pemilu 2019 ini sangat rentan terhadap isu-isu yang bermuatan tentang agama. (M/S200180010)

(10a) Zaman dulu seseorang bertemu dengan kiai, yang dipikirkan adalah kiai tersebut spesialisasi ilmu bidang apa. (M/S200180010)

(11a) Saat ini jika ada seseorang yang bertemu kiai, pertanyaannya adalah kiai itu mendukung siapa. (M/S200180010)

(12a) Agama menjadi landasan bernegara, berbangsa, dan berpolitik. (M/S200180010)

(13a) Agama tidak boleh dipolitisasi, itu mampu menghancurkan kesatuan dan keamanan bangsa Indonesia, khususnya di Kabupaten Klaten (M/S200180010)

(14a) Anak-anak muda, jangan menggunakan kendaraan untuk meresahkan warga (M/S200180010)

(15a) Hal ini mengganggu pendengaran para pengguna jalan yang lainnya (M/S200180010)

(16a) Pesan terakhir kepada ormas, silakan menyebarluaskan pesan-pesan damai terkait pelaksanaan pemilu (M/S200180010)

Hasil penelitian ini relevan dengan penelitian Santosa dan Sabardila (2018) yang meneliti Analisis Kesalahan Berbahasa Pidato Mahasiswa MPB-UMS yang Memerankan Diri menjadi Calon Kepala Daerah Kabupaten Blora. Penelitian tersebut juga menemukan kesalahan penggunaan konjungsi dan pleonasme.

\section{Kesalahan Bidang Sintaksis}

Analisis kesalahan berbahasa bidang sintaksis menyangkut urutan kata, kepaduan, susunan frasa, kepaduan kalimat, dan logika kalimat (Markhamah dan Sabardila, 2014). Adapun temuan contoh mengenai kesalahan bidang sintaksis disajikan sebagai berikut.

(19) Bagi para ibu-ibu dimohon untuk tidak secara cepat menyebarkan segala berita yang diterima melalui aplikasi Whatssap atau sosial media yang lainnya. (M/S200180010)

(20) Yang terhormat, Bupati Klaten, Yang terhormat jajaran musyawarah pimpinan daerah. Yang terhormat Kodim Klaten. Yang terhormat, dan yang saya banggakan masyarakat Klaten dan seluruh hadirin yang tidak mampu saya sebutkan satu persatu dalam acara Apel Siaga Pemilu. (M/S200180010)

(21) Jika diandaikan lautan menjadi tinta dan pohon-pohon itu menjadi pena, maka tidak mampu menulis nikmat-nikmat Allah yang sangat banyak $(\mathrm{M} / \mathrm{S} 200180010)$

(22) Apalagi kita menghitung nikmat-nikmat Allah yang sangat banyak. (M/S200180010)

(23) Karena masyarakat ini adalah elemen yang terpenting, yang menjadi titik ukur, titik tolak keberhasilan Pemilu pada tahun 2019 ini. (M/S200180010) 
(24) Masyarakat sebagai akar bawah yang menjadi korban, menjadi pelaku, menjadi partisipan di dalam Pemilu. (M/S200180010)

(25) Menjadi korban apabila Pemilu itu tidak sukses, terjadi kekacauan, terjadi perpecahan di masyarakat maka masyarakat berposisi sebagai korban. (M/S200180010)

(26) Masyarakat berposisi sebagai partisipan. Masyarakat berhak menentukan pilihannya. (M/S200180010)

(27) Pesan yang pertama, yang ingin saya sampaikan kepada masyarakat (M/S200180010)

(28) Masyarakat tidak diperkenankan untuk melanggar peraturan-peraturan yang secara umum dibuat untuk menjaga kedamaian khususnya di kota ini, di Kabupaten Klaten (M/S200180010)

(29) Umumnya di Indonesia, peraturan-peraturan itu dibuat demi keberlangsungan, demi kecintaan kita terhadap kabupaten Klaten yang dalam bahasa Jawa disebutkan adem ayem (M/S200180010)

(30) Yang berarti dengan ketentraman, dengan kebersamaan kita mewujudkan Klaten yang menjadi panutan bagi Kabupaten yang lain. (M/S200180010)

(31) Masyarakat tidak diperkenankan untuk mengunggah segala hal, baik video, baik tulisan yang berpotensi untuk menghancurkan kesatuan dan persatuan persaudaraan rakyat Indonesia (M/S200180010)

Kesalahan yang terdapat dalam data (19), (20), (21), (22) dan (28), berupa kesalahan penggunaan kata yang mubazir. Penggunaan diksi data (19) para dan ibu-ibu seharusnya cukup ditulis $i b u-i b u$ karena arti dari $i b u-i b u$ sendiri sudah banyak, jika ditambahkan para maka akan timbul arti yang mubazir. Penggunaan kata yang mubazir dapat menjadikan kalimat menjadi tidak efektif (Utami, 2018). Pada data (20), terdapat kesalahan penggunaan kata mubazir. Penggunaan kata pada kalimat seluruh hadirin yang tidak mampu saya sebutkan satu persatu dalam acara Apel Siaga Pemilu seharusnya cukup ditulis masyarakat Klaten karena arti dari seluruh hadirin sendiri sudah merujuk pada masyarakat jika ditambahkan kata satu persatu maka akan timbul arti yang mubazir. Pada data (21) dan (22) juga terdapat kesalahan penggunaan kata mubazir. Penggunaan kata pada kalimat nikmat-nikmat Allah yang sangat banyak seharusnya cukup ditulis nikmat Allah yang banyak atau juga bisa nikmat-nikmat Allah karena arti nikmat-nikmat sudah merujuk pada arti banyak, jika ditambahkan kata sangat banyak atau banyak maka akan menimbulkan arti yang mubazir. Pada data (28) terdapat kesalahan penggunaan kata mubazir. Pada data (28) tertulis Masyarakat tidak diperkenankan untuk melanggar peraturan-peraturan yang dibuat untuk menjaga kedamaian khususnya di Kabupaten Klaten. Jika ditambahkan kata di kota ini maka akan menimbulkan makna yang sama dengan Kabupaten Klaten sehingga akan terjadi kemubaziran. Data (23), (24), (25), (26), (27), dan (29) sampai (31) terdapat kesalahan penggunaan repetisi. Data (23) terdapat repetisi kata yang, data ini juga terdapat kesalahan penggunaan konjungsi. Pada data (24) terdapat repetisi kata menjadi. Data (25) juga terdapat repetisi kata terjadi. Data (26) terdapat kesalahan berupa ketidakefektifan kalimat. Pada data (26) terdapat penggunaan kata depan yang sama dan maknanya juga sama sehingga akan lebih efektif jika dijadikan satu kalimat saja. Data (26) cukup ditulis Masyarakat berposisi sebagai partisipan dan berhak menentukan pilihannya. Pada data (27), terdapat kesalahan penggunaan repetisi yang. Data (29) juga terdapat kesalahan penggunaan repetisi kata demi. Pada data (30) ditemukan kesalahan 
penggunaan repetisi kata dengan. Selain itu, data (31) ditemukan kesalahan penggunaan repetisi kata baik. Adapun pembenaran data (19) sampai (31) adalah sebagai berikut.

(19a) $\boldsymbol{I} \boldsymbol{b} \boldsymbol{u}$-ibu dimohon untuk tidak secara cepat menyebarkan segala berita yang diterima melalui aplikasi Whatssap atau sosial media yang lainnya. (M/S200180010)

(20a) Yang terhormat, Bupati Klaten. Yang terhormat, jajaran musyawarah pimpinan daerah. Yang terhormat, Kodim Klaten. Yang terhormat dan saya banggakan masyarakat Klaten dalam acara Apel Siaga Pemilu. (M/S200180010)

(21a) Jika diandaikan lautan menjadi tinta dan pohon-pohon itu menjadi pena, maka tak mampu menulis nikmat Allah yang banyak (M/S200180010)

(22a) Apalagi kita menghitung nikmat Allah yang banyak. (M/S200180010)

(23a) Masyarakat atau elemen terpenting yang menjadi titik ukur, titik tolak keberhasilan pemilu pada tahun 2019 ini. (M/S200180010)

(24a) Masyarakat sebagai akar bawah yang menjadi korban, pelaku, dan partisipan di dalam pemilu. (M/S200180010)

(25a) Masyarakat menjadi korban apabila pemilu itu tidak sukses, terjadi kekacauan dan perpecahan karena masyarakat berposisi sebagai korban. (M/S200180010)

(26a) Masyarakat berposisi sebagai partisipan dan berhak menentukan pilihan. (M/S200180010)

(27a) Pesan yang pertama saya sampaikan kepada masyarakat (M/S200180010)

(28a) Masyarakat tidak diperkenankan untuk melanggar peraturan-peraturan yang dibuat untuk menjaga kedamaian, khususnya di Kabupaten Klaten (M/S200180010)

(29a) Umumnya di Indonesia, peraturan-peraturan itu dibuat demi keberlangsungan dan kecintaan kita terhadap Kabupaten Klaten yang dalam bahasa Jawa disebutkan adem ayem (M/S200180010)

(30a) Hal itu berarti dengan ketentraman dan kebersamaan, kita mewujudkan Klaten yang menjadi panutan bagi kabupaten yang lain. (M/S200180010)

(31a) Masyarakat tidak diperkenankan untuk mengunggah segala hal, baik video maupun tulisan yang berpotensi untuk menghancurkan kesatuan dan persatuan persaudaraan rakyat Indonesia (M/S200180010)

Hasil penelitian ini relevan dengan penelitian Santosa dan Sabardila (2018) yang meneliti Analisis Kesalahan Berbahasa Pidato Mahasiswa MPB-UMS yang Memerankan Diri menjadi Calon Kepala Daerah Kabupaten Blora. Penelitian ini juga menghasilkan temuan berupa kesalahan penggunaan kata yng mubazir dan pleonasme.

\section{Kesalahan Bidang Sosiolinguistik}

Kesalahan berbahasa bidang sosiolinguistik menyangkut penggunaan campur kode dalam kalimat. Adapun temuan mengenai kesalahan bidang sosiolinguistik disajikan sebagai berikut.

(32) Pada, point yang ketiga masyarakat bijak dalam menggunakan media sosial (M/S200180010)

(33) Hal ini menjadi point penting yang harus dijaga oleh kepolisian (M/S200180010)

(34) Yang keempat, point yang keempat, bijaksana dalam menyebarluaskan informasi $(\mathrm{M} / \mathrm{S} 200180010)$

Kesalahan berbahasa pada data tersebut merupakan kesalahan bidang 
sosiolinguistik. Data (30), (31), dan (32) tersebut merupakan kesalahan alih kode. Penutur berpidato menggunakan bahasa Indonesia, akan tetapi di sela-sela tuturannya penutur menggunakan bahasa asing, yaitu bahasa Inggris. Data (30), (31), dan (32) terdapat kesalahan alih kode penggunaan kata point yang jika diartikan ke dalam bahasa Indonesia adalah titik. Data (32) ini juga terdapat kesalahan penggunaan kata depan yaitu yang. Adapun pembenaran data (30) sampai (32) adalah sebagai berikut.

(30a) Titik ketiga adalah masyarakat bijak dalam menggunakan media sosial (M/S200180010)

(31a) Hal ini menjadi titik penting yang harus dijaga oleh kepolisian (M/S200180010)

(32a) Titik yang keempat, bijaksana dalam menyebarluaskan informasi (M/S200180010)

Hasil penelitian ini relevan dengan penelitian Yuniawan (2005) yang meneliti Campur Kode pada Masyarakat Etnik Jawa-Sunda: Kajian Sosiolinguistik dalam Ranah Pemerintahan Di Kabupaten Brebes. Pada penelitian ini juga ditemukan kesalahan di bidang sosiolinguistik yaitu adanya campur kode bahasa Inggris ke dalam tuturan bahasa Indonesia.

\section{KESIMPULAN}

Berdasarkan hasil penelitian, dapat disimpulkan bahwa pada pidato polisi di Klaten ditemukan beberapa kesalahan berbahasa, di antaranya adalah sebagai berikut. Pertama, kesalahan bidang fonologi. Dalam kesalahan bidang fonologi ditemukan lima bentuk kesalahan. Kedua, kesalahan di bidang ejaan. Dalam bidang ejaan, ditemukan satu kesalahan. Ketiga, kesalahan bidang morfologi ditemukan 10 data kesalahan berbahasa yang meliputi satu pleonasme dan sembilan kesalahan penggunaan kata depan. Keempat, kesalahan pada bidang sintaksis ditemukan 13 data yang meliputi lima penggunaan kata yang mubazir, enam penggunaan repetisi, dan satu ketidakefektifan kalimat. Kelima, kesalahan di bidang sosiolinguistik. Dalam kesalahan bidang sosiolinguistik ditemukan tiga data yang di antaranya merupakan tiga kesalahan alih kode.

\section{UCAPAN TERIMA KASIH}

Ucapan terima kasih kami sampakain kepada berbagai pihak yang mendukung kelancaran penyelenggarakan proses penelitian serta penulisan artikel ilmiah ini sehingga dapat dipublikasikan.

\section{REFERENSI}

Afifah, N., \& Hasibuan, N. S. (2018). Analisis kesalahan berbahasa pada penulisan media luar ruang di wilayah Kota Medan. Linguistik: Jurnal Bahasa dan Sastra, 2(1), 14-37.

Afifah, L., \& Widodo, P. (2015). Kesalahan deiksis dalam karangan mahasiswa pada Niveau A2 di Jurusan Sastra Jerman UM. Jurnal Ling Tera, 2(1), 27-37. doi: https://doi.org/10.21831/lt.v2i1.5413 
Afrizal. (2016). Metode Penelitian Kualitatif: Sebuah Upaya Mendukung Penggunaan Penelitian Kualitatif dalam Berbagai Disiplin Ilmu. Jakarta: Raja Grafindo Persada.

Chaer, A. (2007). Linguistik Umum. Jakarta: Rineka Cipta.

Johan, G.M., \& Ghasya, D.A.V. (2017). Analisis kesalahan morfologis dalam proses diskusi siswa sekolah dasar. Jurnal Visipena, 8(1), 124-134.

Johan, G.M., \& Yusrawati. (2019). Conferencing approach dalam meningkatkan kemampuan menulis siswa sekolah dasar: sebuah perspektif. No Eds. Proceeding of Seminar Nasional Pendidikan FKIP Universitas Sultan Ageng Tirtayasa, Serang, Indonesia. Retrieved from http://jurnal.untirta.ac.id/index.php/psnp/article/viewFile/5755/4130

Hasyim, M. (2008). Faktor penentu penggunaan bahasa pada masyarakat tutur Makassar: Kajian sosiolinguistik di Kabupaten Gowa. Humaniora, 20(1), 7588. doi: https://doi.org/10.22146/jh.v20i1.921

Kim, S.J. (2015). A comparison of phonological error patterns in the single word and spontaneous speech of children with speech sound disorders. Phonetics and Speech Sciences, 7(3), 165-173.

Markhamah, \& Sabardila, A. (2013). Analisis Kesalahan dan Kesantunan Berbahasa. Surakarta: Muhammadiyah University Press.

Markhamah, \& Sabardila, A. (2014). Analisis Kesalahan dan Karakteristik Bentuk Pasif. Surakarta: Muhammadiyah University Press.

Marsono. 2015. Meningkatkan keterampilan pidato melalui perpaduan metode simulasi lomba pidato bahasa Indonesia dengan model talking stick pada siswa kelas X11 IPA-2 SMA Negeri Meulaboh Kabupaten Aceh Barat. Jurnal Visipena, 6(2), $11-19$.

Mokhtar, M. (2000). Interferensi morfologis penutur bahasa Bugis dalam berbahasa Indonesia. Humaniora, 12(2), 25-39. doi: https://doi.org/10.22146/jh.v12i2.693

Noviastuti, L., Arifah, F.N., \& Murtiani, A. (2017). Tata Bahasa Indonesia. Yogyakarta: Araska.

Nurwicaksono, B.D., \& Amelia, D. (2018). Analisis kesalahan berbahasa Indonesia pada teks ilmiah mahasiswa. Jurnal AKSIS: Jurnal Pendidikan Bahasa dan Sastra Indonesia, 2(2), 138-153. doi: https://doi.org/10.21009/AKSIS.020201

Pateda, M. 1990. Sosiolinguistik. Bandung: Angkasa.

Purwahida, R. (2018). Problematika Pengembangan Modul Pembelajaran Baca Tulis Anak Usia Sekolah Dasar. Aksis: Jurnal Pendidikan Bahasa dan Sastra Indonesia 2(1). 118-134. doi: doi.org/10.21009/AKSIS.020108 
Rahmawati, L.E., Kartikasari, F., \& Sukoco, Y.W.T. (2014). Analisis kesalahan berbahasa pada 20 paket soal ujian nasional bahasa Indonesia SMP 2012/2013. Jurnal Varia Pendidikan, 26(2), 129-140. doi: https://doi.org/10.23917/varidika.v26i2.682

Rohmadi, M., \& Nasucha, Y. (2015). Dasar-dasar Penelitian Bahasa Sastra dan Pengajaran. Surakarta: Pustaka Briliant.

Santosa, T., \& Sabardila, A. (2018). Analisis kesalahan berbahasa pidato mahasiswa MPBI-UMS yang memerankan diri menjadi calon kepala daerah Kabupaten Blora. Jurnal Penelitian Humaniora, 19(2), 17-27. doi: https://doi.org/10.23917/humaniora.v19i2.6043

Setyawati, N. (2010). Analisis Kesalahan Berbahasa. Jakarta: Balai Pustaka.

Sudaryanto. (2015). Metode dan Aneka Teknik Analisis Data. Yogyakarta: Sanata Dharma University Press.

Suhartatik. (2018). Makna Leksikal Bahasa Madura Keadaan Alam Nelayan di Pesisir Kepulauan Sumenep. Aksis: Jurnal Pendidikan Bahasa dan Sastra Indonesia 2(1). 107-126. doi: doi.org/10.21009/AKSIS.020107

Thoyib, T., \& Hamidah, H. (2018). Interferensi fonologis bahasa Arab: Analisis kontrastif fonem bahasa Arab terhadap fonem bahasa Indonesia pada mahasiswa Universitas Al Azhar bukan jurusan Sastra Arab. Jurnal Al-Azhar Indonesia Seri Humaniora, 4(2), 63-71.

Utami, P.S.N. (2018). Analisis kesalahan keefektifan kalimat pada teks biografi karangan siswa kelas VIII SMP Negeri 158 Jakarta. Jurnal AKSIS: Jurnal Pendidikan Bahasa dan Sastra Indonesia, 2(2), 190-201. doi: https://doi.org/10.21009/AKSIS.020204

Wiyanti, E. (2014). Peran minat membaca dan penguasaan kosakata terhadap keterampilan berbicara bahasa Indonesia. Jurnal DEIKSIS, 6(2), 89-100.

Yuniawan, T. (2005). Campur kode pada masyarakat etnik Jawa-Sunda: Kajian sosiolinguistik dalam ranah pemerintahan di Kabupaten Brebes. Jurnal Humaniora, 17(1), 89-99. doi: https://doi.org/10.22146/jh.v17i1.832 